\title{
Correction to: The influence of stiffener geometry on flexural properties of 3D-printed polylactic acid (PLA) beams
}

\author{
Silas Z. Gebrehiwot ${ }^{1} \cdot$ Leonardo Espinosa-Leal $^{2}$ · J. N. Eickhof ${ }^{3} \cdot$ L. Rechenberg ${ }^{3}$
}

Published online: 2 September 2020

(c) The Author(s) 2020

\section{Correction to: Progress in Additive Manufacturing https://doi.org/10.1007/s40964-020-00146-2}

The publication of this article unfortunately contained a mistake. The name of the second author was wrong, correct it should be L. Expinosa Leal instead of E.L. Leonardo.

The original article has been corrected.

The original article can be found online at https://doi.org/10.1007/ s40964-020-00146-2.

Silas Z. Gebrehiwot

silas.gebrehiwot@arcada.fi

1 Material and Energy Engineering, Arcada University of Applied Sciences, Helsinki, Finland

2 Business Management and Analytics, Arcada University of Applied Sciences, Helsinki, Finland

3 Mechanical Engineering, Frankfurt University of Applied Sciences, Frankfurt, Germany 